\section{Intraocular pressure in anaesthetized dogs given flumazenil with and without prior administration of midazolam}

Alan A. Artru MD
This study examined the effect of flumazenil, a benzodiazepine antagonist, on aqueous humour pressure in dogs receiving either midazolam or no benzodiazepine. Twenty-four halothaneanaesthetized dogs were assigned to one of four groups. Group I $(n=6)$ received saline iv at 0,45 and $90 \mathrm{~min}$. Group $2(n=6)$ received saline at $0 \mathrm{~min}$. flumazenil $0.0025 \mathrm{mg} \cdot \mathrm{kg}^{-1}$ iv at 45 min and flumazenil $0.16 \mathrm{mg} \cdot \mathrm{kg}^{-1}$ at $90 \mathrm{~min}$. Group $3(\mathrm{n}=6)$ received midazolam $1.6 \mathrm{mg} \cdot \mathrm{kg}^{-1}$ at 0 min followed by continuous iv infusion $\left(1.25 \mathrm{mg} \cdot \mathrm{kg}^{-1} \cdot \mathrm{hr}^{-1}\right)$. Flumazenil was given at 45 and 90 min as in Group 2. In Group $4(n=6)$ aqueous humour pressure was elevated to about $35 \mathrm{mmHg}$ then midazolam and flumazenil were given as in Group 3. Aqueous humour pressure was determined using a 30-gauge needle placed into the anterior chamber. Saline or flumazenil produced no change in aqueous humour pressure in Groups $I$ and 2. In Groups 3 and 4, midazolam decreased aqueous humour pressure from $18 \pm 2$ $\mathrm{mmHg}$ (mean $\pm S D)$ to $14 \pm 3 \mathrm{mmHg}(P<0.001)$ and from 34 $\pm 5 \mathrm{mmHg}$ to $31 \pm 3 \mathrm{mmHg}(P<0.01)$ respectively. Flumazenil given during continuous infusion of midazolam produced increases of aqueous humour pressure of $2 \pm I(P<$ $0.01)$ to $5 \pm 2 \mathrm{mmHg}(P<0.01)$ that lasted $\leq 12 \mathrm{~min}$. It is concluded that at both normal and elevated aqueous humour pressures flumazenil produces statistically significant but clinically unimportant increases of aqueous humour pressure in

\section{Key words}

ANAESTHETICS, INTRA VENOUS: midazolam; ANTAGONISTS, BENZODIAZEPINE: flumazenil; EYE: intraocular pressure; HYPNOTICS: midazolam.

From the Department of Anesthesiology, University of Washington School of Mcdicine, Seattle, Washington.

Address correspondence to: Dr. A.A. Artru, Department of Anesthesiology, RN-10, University of Washington School of Medicine, Scattle, WA 98195.

Accepted for publication 15th November 1990. anaesthetized dogs receiving midazolam, but not in dogs given no benzodiazepine.

Nous avons mesuré l'effet du flumazénil, un antidote des benzodiazépines, sur la pression intra-oculaire $(P I O)$ de chiens traités ou non au midazolam. Nous avions quatre groupes de six chiens anesthésiés à l'halothane chez qui, nous mesurions la pression de la chambre antérieure de l'ail au moyen d'une aiguille de calibre 30. On injectait par voie intraveineuse, de la solution saline aux chiens du groupe I aux temps 0,45 et 90 min. Ceux du groupe 2 recevaient la même solution au temps 0 puis du flumazénil ivà raison de $2,5 \mu \mathrm{g} \cdot \mathrm{kg}^{-1}$ à 45 min et $160 \mu \mathrm{g} \cdot \mathrm{kg}^{-1}$ à 90 min. Les sujets du groupe 3 avaient un régime de midazolam iv initié au temps 0 avec un bolus de $1,6 \mathrm{mg} \cdot \mathrm{kg}^{-1}$ suivi d' une perfusion de $1,25 \mathrm{mg} \cdot \mathrm{kg}^{-1} \cdot \mathrm{h}^{-1}$ et on leur injectair ensuite les mêmes doses de flumazénil qu'à ceux du groupe 2. Chez les animaux du groupe 4, on faisait d'abord augmenter la PIO jusqu'à $35 \mathrm{mmHg}$ pour ensuite les traiter comme ceur du groupe 3. Ni la solution saline ni le flumazénil ne modifièrent la PIO des chiens des groupes I et 2 . Notons qu'avec le midazolam, la PIO passait de $18 \pm 2$ (moyenne \pm écart-type) à $14 \pm 3 \mathrm{mmHg}(P<$ $0,001)$ chez les animaux du groupe 3 et de $34 \pm 5$ à $3 I \pm 3$ $\mathrm{mmHg}(P<0,01)$ chez ceux du groupe 4 . Injectées pendant la perfusion de midazolam, les deux doses de flumazénil faisaient augmenter la PlO de $2 \pm 1 \mathrm{mmHg}(P<0,01)$ et de $5 \pm 2 \mathrm{mmHg}$ $(P<0.01)$ pendant moins de 12 minutes. Il semble done que la PIO de chiens anesthésiés qui reçoivent du midazolam, qu' elle soit normale ou élevée au départ, puisse augmenter légèrement mais de façon statistiquement significative avec l'injection de flumazénil.

Midazolam is reported to be useful for the control of intraocular pressure (IOP). In 30 patients free of opthalmological disease, midazolam $0.15 \mathrm{mg} \cdot \mathrm{kg}^{-1}$ iv decreased IOP at induction of anaesthesia, and minimized the increase of IOP that accompanied subsequent administration of succinylcholine and tracheal intubation. ' In 30 
patients undergoing ophthalmological surgery, midazolam $0.15 \mathrm{mg} \cdot \mathrm{kg}^{-1}$ iv decreased IOP at 2, 5 and $10 \mathrm{~min}$ after induction of anaethesia. ${ }^{2}$ In 20 patients undergoing cataract extraction, midazolam $0.15 \mathrm{mg} \cdot \mathrm{kg}^{-1}$ iv decreased IOP at induction of anaesthesia, and minimized the increase of IOP that accompanied subsequent administration of succinylcholine and tracheal intubation. ${ }^{3}$ It was speculated that these beneficial effects of benzodiazepines (and central nervous system depressants generally) on IOP occurred due to a combination of effects including relaxation of extraocular muscles, increased facility of aqueous humour outflow and depression of the diencephalon. ${ }^{4.5}$ As a result of these beneficial effects on IOP, midazolam and other benzodiazepines are recommended for control of IOP, to relieve anxiety and to produce sedation and amnesia during ophthalmological surgery when local anaesthesia is used, and for general anaesthesia for more extensive ophthalmological surgery. ${ }^{6-9}$

Flumazenil is a new benzodiazepine antagonist that rapidly reverses the central nervous system depression caused by midazolam in both patients and dogs. ${ }^{10,11}$ Recent studies have recommended the use of flumazenil to reverse unwanted benzodiazepine effects during opthalmological surgery. In aged patients undergoing opthalmological surgery with local or general anaesthesia, flumazenil was reported to reverse midazolam-induced "paradoxical" or anxiogenic reactions, and also to reverse upper airway obstruction resulting from midazolaminduced sedation. ${ }^{9}$ However, the effects of flumazenil on IOP have not been thoroughly examined. It is possible that using flumazenil to reverse the central nervous system effects of midazolam might also reverse the beneficial effects of midazolam on IOP, resulting in increased IOP. Increase of IOP is of concern because it may cause extrusion of intraocular contents (if the cornea or sclera is damaged) or decrease corneal or retinal blood flow (if the cornea or sclera are intact). ${ }^{6}$

The present studies were designed to examine the effects of flumazenil on IOP in anaesthetized dogs. One purpose of these studies was to determine the effect of flumazenil on IOP in dogs receiving midazolam. Two doses of flumazenil were administered. The two doses were chosen based on previous reports in dogs that the lower dose was an effective antagonist dose (because it reversed most of the central nervous system depression caused by midazolam), and that the higher dose exceeded that necessary to reverse benzodiazepine effects (because it completely reversed midazolam-induced central nervous system depression and in addition produced some signs of central nervous system excitation). ${ }^{12}$

A second purpose of the present studies was to determine the effect of flumazenil on IOP in dogs not receiving midazolam. The effects of flumazenil in the absence of midazolam have not been thoroughly examined. Thus, it is not known whether the effects of flumazenil (if any) on IOP might result solely from the reversal of benzodiazepine effects, or may result in part from a direct agonist action of flumazenil on extraocular muscles, aqueous humour outflow, activity of the diencephalon, etc.

A third purpose of the present studies was to determine the effects of flumazenil on IOP when IOP was increased. The effects of benzodiazepines and/or benzodiazepine antagonists at increased IOP are not known. Thus, it is possible that the effects of flumazenil (if any) on IOP are minimal at normal IOP but may be exaggerated at increased IOP.

\section{Methods}

\section{Animal preparation}

This study was approved by the Animal Care Committee of the University of Washington. Twenty-four unmedicated mongrel dogs (weights $14-21 \mathrm{~kg}$ ) were studied. Anaesthesia was induced with halothane $(>1.5 \%$ in spired concentration) and nitrous oxide $\left(\mathrm{N}_{2} \mathrm{O}, 66 \%\right.$, inspired) in oxygen. The trachea was intubated, expired $\mathrm{CO} 2$ was continuously monitored (Beckman Medical Gas Analyzer, Model LB2, Beckman Instruments, Inc. Fullerton, CA) and ventilation was regulated by a servo controller to maintain expired $\mathrm{CO}_{2}$ at normocapnia. The right femoral artery was cannulated to permit arterial blood sampling for blood gas analysis and to permit continuous monitoring of systemic arterial blood pressure and heart rate. Mean arterial blood pressure (MAP) was determined by electronic integration. A urinary catheter was inserted, the right femoral vein was cannulated for saline and drug administration and temperature was monitored by a nasopharyngeal thermistor probe. Intravenous infusion of pancuronium $2-4 \mathrm{mg} \cdot \mathrm{hr}^{-1}$ maintained muscle relaxation. Temperature was maintained at 37.0 $\pm 0.5^{\circ} \mathrm{C}$ by heat lamps. Depletion of vascular volume was minimized by continuous infusion of saline at 4-6 $\mathrm{ml} \cdot \mathrm{kg}^{-1} \cdot \mathrm{hr}^{-1}$

The animal was then turned to the prone position and the head slightly elevated and fixed in a stereotaxic frame. A 30-gauge needle was inserted at the lateral cornealscleral junction and advanced horizontally into the anterior chamber. Care was taken to place the needle in such a way that no aqueous humour was lost from the anterior chamber and that the normal curvature of the cornea was maintained. ${ }^{13}$ Needle placement was considered satisfactory if variability of intraocular pressure with ventilation (previously reported with both invasive ${ }^{13}$ and noninvasive $^{6,14}$ measurement of intraocular pressure) was ob- 
TABLE I Baseline systemic values (mean $\pm \mathrm{SD}$ )

\begin{tabular}{|c|c|c|c|c|}
\hline & $\begin{array}{l}\text { Group } 1^{*} \\
(n=6)\end{array}$ & $\begin{array}{l}\text { Group } 2^{*} \\
(n=6)\end{array}$ & $\begin{array}{l}\text { Group } 3 \dagger \\
(n=6)\end{array}$ & $\begin{array}{l}\text { Group } 4 t \\
(n=6)\end{array}$ \\
\hline $\mathrm{PaO}_{2}(\mathrm{mmHg})$ & $146 \pm 17$ & $155 \pm 19$ & $145 \pm 14$ & $156 \pm 11$ \\
\hline $\mathrm{PaCO}_{2}(\mathrm{mmHg})$ & $37.1 \pm 2.5$ & $37.7 \pm 2.7$ & $38.4 \pm 1.8$ & $36.6 \pm 2.1$ \\
\hline $\mathrm{pH}$ & $7.34 \pm .04$ & $7.34 \pm .03$ & $7.33 \pm .05$ & $7.35 \pm .04$ \\
\hline Bicarbonate $\left(\mathrm{mEq} \cdot 1^{-1}\right)$ & $19.4 \pm 2.4$ & $19.3 \pm 1.7$ & $20.0 \pm 2.5$ & $19.1 \pm 2.1$ \\
\hline Hacmoglobin $\left(g \cdot \mathrm{dl}^{-1}\right)$ & $14.6 \pm 0.8$ & $14.4 \pm 0.9$ & $14.7 \pm 1.4$ & $14.2 \pm 1.1$ \\
\hline \multicolumn{5}{|l|}{ Mean arterial blood } \\
\hline pressure (mmHg) & $112 \pm 9$ & $112 \pm 14$ & $113 \pm 12$ & $108 \pm 10$ \\
\hline Heart rate (beats $\cdot \min ^{-1}$ ) & $104 \pm 11$ & $98 \pm 15$ & $111 \pm 12$ & $114 \pm 16$ \\
\hline \multicolumn{5}{|l|}{ Temperature, } \\
\hline nasopharyngeal $\left({ }^{\circ} \mathrm{C}\right)$ & $37.0 \pm 0.4$ & $37.2 \pm 0.4$ & $37.1 \pm 0.4$ & $37.4 \pm 0.4$ \\
\hline
\end{tabular}

*Anaesthesia maintained with halothane $(0.5 \%$ end-expired) and nitrous oxide ( $66 \%$ inspired) in oxygen.

tAnaesthesia maintained with midazolam $\left(1.6 \mathrm{mg} \cdot \mathrm{kg}^{-1}\right.$ iv followed by continuous infusion at

$\left.1.25 \mathrm{mg} \cdot \mathrm{kg}^{-1} \cdot \mathrm{hr}^{-1}\right)$, and halothane $(0.5 \%$ end-expired) and nitrous oxide (66\% inspired) in oxygen.

served. A short length of fine nylon tubing was attached to the intraocular needle to permit measurement of aqueous humour pressure in the anterior chamber. Aqueous humour pressure was measured using a strain-gauge transducer (Statham P 23AA) placed at eye level. The mid-ocular line was used as the zero reference. Drying of the cornea and sclera was minimized by continuous infusion of a saline solution onto the surface of the eye at 7 $\mathrm{ml} \cdot \mathrm{hr}^{-1}$ using a syringe pump. Lidocaine was added to the saline solution (to achieve a $0.2 \%$ concentration) for topical analgesia. ${ }^{13}$ Wound edges were infiltrated with bupivacaine $(0.5 \%)$, and the concentration of halothane was decreased to $0.5 \%$ (end-expired value determined by gas chromatography, $\mathrm{N}_{2} \mathrm{O}$ unchanged).

After stabilization of aqueous humour pressure and systemic values (at least $30 \mathrm{~min}$ later) baseline measurements were made. Animals then were assigned randomly to one of three groups. Group 1 ( $n=6$, time controls) received $10 \mathrm{ml}$ saline $i v$ at this time $(0 \mathrm{~min})$ and at 45 and $90 \mathrm{~min}$. Group $2(n=6)$ received $10 \mathrm{ml}$ saline at $0 \mathrm{~min}$, flumazenil $0.0025 \mathrm{mg} \cdot \mathrm{kg}^{-1}$ iv at $45 \mathrm{~min}$ and flumazenil $0.16 \mathrm{mg} \cdot \mathrm{kg}^{-1}$ iv at $90 \mathrm{~min}$. Each dose of flumazenil was given over $60 \mathrm{sec}$. Group $3(n=6)$ received midazolam iv at $0 \mathrm{~min}$, flumazenil $0.0025 \mathrm{mg} \cdot \mathrm{kg}^{-1}$ at $45 \mathrm{~min}$ and flumazenil $0.16 \mathrm{mg} \cdot \mathrm{kg}^{-1}$ at $90 \mathrm{~min}$. Midazolam was given as $1.6 \mathrm{mg} \cdot \mathrm{kg}^{-1}$ over ten minutes followed by continuous infusion at $1.25 \mathrm{mg} \cdot \mathrm{kg}^{-1} \cdot \mathrm{hr}^{-1}$. Infusion of midazolam continued until the end of the study (135 $\mathrm{min}$ ). Group $4(n=6)$ studies were undertaken after the results from groups $1-3$ indicated minimal change of aqueous humour pressure following administration of flumazenil. In Group 4 aqueous humour pressure was increased to about $35 \mathrm{mmHg}$ by attaching a $\mathrm{T}$-connector to the intraocular needle and infusing saline at about $6 \mu \mathrm{l} \cdot \mathrm{min}^{-1}$ using a variable speed syringe pump. The infusion rate was adjusted so that aqueous humour pressure was maintained at the desired level for at least $30 \mathrm{~min}$. The infusion then was continued at the same rate and midazolam and flumazenil were given iv as in Group 3. During the experimental period aqueous humour pressure, MAP, heart rate, expired $\mathrm{CO}_{2}$ and temperature were determined continuously. Arterial blood gas tensions and haemoglobin concentration were determined five minutes after each treatment and/or when aqueous humour pressure changed. Aqueous humour pressure was recorded before and after each treatment. Where aqueous humour pressure changed, the magnitude and duration of change and time to peak change were recorded.

Statistical comparisons within groups were made using repeated-measures analysis of variance, and comparisons between groups were made using one-way analysis of variance. Where the calculated $F$ value exceeded the critical value for the 0.05 probability level, the StudentNewman-Keuls' test was used to determine which differences were significant at $P<0.05$. Values are tabulated as mean $\pm \mathrm{SD}$.

\section{Results}

\section{Group 1}

The baseline value for aqueous humour pressure, $16 \pm 3$ $\mathrm{mmHg}$, was not significantly different from the baseline values in group $2,16 \pm 3 \mathrm{mmHg}$, and group $3,18 \pm 2$ $\mathrm{mmHg}$. Variability of aqueous humour pressure with ventilation was $1-4 \mathrm{mmHg}$ and was not significantly different from that in Groups 2 and 3. Baseline systemic values also did not differ among groups (Table I). Intravenous administration of saline at 0,45 and $90 \mathrm{~min}$ caused no significant change in aqueous humour pressure, variability of aqueous humour pressure or systemic values. 
TABLE Il Efects of midazolam and flumazenil on aqueous humour pressure in Group 3, $n=6$ and Group $4, n=6($ mean \pm SD)

\begin{tabular}{|c|c|c|c|c|c|}
\hline & \multicolumn{5}{|c|}{ Aqueous humour pressure } \\
\hline & $\begin{array}{l}\text { Pre. } \\
\text { treatment } \\
(m m H g)\end{array}$ & $\begin{array}{l}\text { Post- } \\
\text { treatment } \\
\left(m m H_{g}\right)\end{array}$ & $\begin{array}{l}\text { Magnitude } \\
\text { of change } \\
(\mathrm{mmHg})\end{array}$ & $\begin{array}{l}\text { Duration } \\
\text { land rangel } \\
\text { of change } \\
(\text { min) }\end{array}$ & $\begin{array}{l}\text { Time to } \\
\text { peak } \\
\text { (min) }\end{array}$ \\
\hline \multicolumn{6}{|l|}{ Group 3} \\
\hline $\begin{array}{l}\text { Midazolam } \\
(0 \text { min }) \\
\text { Flumazenil }\end{array}$ & $18 \pm 2^{*}$ & $14 \pm 3 \dagger$ & $-4 \pm 2$ & $\begin{array}{c}45 \\
{[45]}\end{array}$ & - \\
\hline $\begin{array}{l}0.0025 \mathrm{mg} \cdot \mathrm{kg}^{-1} \\
(45 \mathrm{~min})\end{array}$ & $14 \pm 3$ & $16 \pm 4 \ddagger$ & $+2 \pm 2$ & $\begin{array}{l}8.0=3.6 \\
{[3-12]}\end{array}$ & $3.7 \pm 2.0$ \\
\hline \multicolumn{6}{|l|}{ Flumazenil } \\
\hline $\begin{array}{l}0.16 \mathrm{mg} \cdot \mathrm{kg}^{-1} \\
(90 \mathrm{~min})\end{array}$ & $14 \pm 3$ & $16 \pm 4 \ddagger$ & $+2 \pm 1$ & $\begin{array}{l}6.6 \pm 2.6 \\
{[3-10]}\end{array}$ & $2.4 \pm 1.5$ \\
\hline \multicolumn{6}{|l|}{ Group 4} \\
\hline $\begin{array}{l}\text { Midazolam } \\
(0 \mathrm{~min})\end{array}$ & $34 \pm 5 \S$ & $31 \pm 3+$ & $-3 \pm 2$ & $\begin{array}{c}45 \\
{[45]}\end{array}$ & \\
\hline \multicolumn{6}{|l|}{ Flumazenil } \\
\hline $\begin{array}{l}0.0025 \mathrm{mg} \cdot \mathrm{kg}^{-1} \\
(45 \mathrm{~min})\end{array}$ & $31 \pm 3$ & $35 \pm 5$ & $+4 \pm 2$ & $\begin{array}{l}4.0 \pm 2.1 \\
{[0-6]}\end{array}$ & $1.7 \pm 0.9$ \\
\hline \multicolumn{6}{|l|}{ Flumazenil } \\
\hline $\begin{array}{l}0.16 \mathrm{mg} \cdot \mathrm{kg}^{-1} \\
(90 \mathrm{~min})\end{array}$ & $31 \pm 3$ & $36 \pm 5 \ddagger$ & $+5 \pm 2$ & $\begin{array}{l}7.3 \pm 1.5 \\
|5-10|\end{array}$ & $2.5 \pm 1.3$ \\
\hline
\end{tabular}

*Baseline aqueous humour pressure for Group 3.

+Significant decrease from pre-midazolam pressure. $P<0.05$

$¥$ \ignificant increase from pre-flumazenil pressure, $P<0.05$.

$\S$ Baseline aqueous humour pressure for Group 4.

\section{Group 2}

Intravenous administration of saline at $0 \mathrm{~min}$ caused no significant change of aqueous humour pressure from baseline values. Similarly, neither dose of flumazenil caused a significant change of aqueous humour pressure. After flumazenil $0.0025 \mathrm{mg} \cdot \mathrm{kg}^{-1}$ aqueous humour pressure was $15 \pm 3 \mathrm{mmHg}$. After flumazenil $0.16 \mathrm{mg} \cdot \mathrm{kg}^{-1}$ aqueous humour pressure was $15 \pm 3 \mathrm{mmHg}$. There were no significant changes in systemic values following saline or either dose of flumazenil.

\section{Group 3}

Intravenous bolus ( $0 \mathrm{~min}$ ) followed by continuous iv infusion of midazolam decreased aqueous humour pressure from $18 \pm 2 \mathrm{mmHg}$ (baseline value) to $14 \pm 3 \mathrm{mmHg}$ (P $<0.001)$ (Table II). The MAP decreased in some animals but the group data did not achieve statistical significance. There were no other accompanying changes in systemic values. Both doses of flumazenil increased aqueous humour pressure compared with that during continuous infusion of midazolam. Flumazenil 0.0025 $\mathrm{mg} \cdot \mathrm{kg}^{-1}$ increased aqueous humour pressure to $16 \pm 4$ $\mathrm{mmHg}(P<0.01)$. The peak increase occurred at $3.7 \pm$
$2.0 \mathrm{~min}$ after this lower dose of flumazenil. Aqueous humour pressure returned to pre-flumazenil values (14 \pm $3 \mathrm{mmHg}$ ) at $8.0 \pm 3.6 \mathrm{~min}$. Flumazenil $0.16 \mathrm{mg} \cdot \mathrm{kg}^{-1}$ increased aqueous humour pressure to $16 \pm 4 \mathrm{mmHg}(P$ $<0.01$ ). The peak increase occurred at $2.4 \pm 1.5 \mathrm{~min}$ after this higher dose of flumazenil. Aqueous humour pressure retumed to pre-flumazenil values $(14 \pm 3$ $\mathrm{mmHg}$ ) at $6.6 \pm 2.6 \mathrm{~min}$. With both doses of flumazenil peak aqueous humour pressure was not significantly different from pre-midazolam (baseline) aqueous humour pressure. There were no accompanying changes in systemic values with either dose of flumazenil.

\section{Group 4}

Intravenous bolus (at 0 time) followed by continuous iv infusion of midazolam decreased aqueous humour pressure from $34 \pm 5 \mathrm{mmHg}$ (bascline value) to $31 \pm 3 \mathrm{mmHg}$ $(P<0.01)$. The MAP decreased in some animals but the group data did not achieve statistical significance. There were no other accompanying changes in systemic values. Flumazenil $0.0025 \mathrm{mg} \cdot \mathrm{kg}^{-1}$ caused no significant change of aqueous humour pressure. Flumazenil $0.16 \mathrm{mg} \cdot \mathrm{kg}^{-1}$ increased aqueous humour pressure from $31 \pm 3 \mathrm{mmHg}$ 
to $36 \pm 5 \mathrm{mmHg}(P<0.01)$. The peak increase occurred at $2.5 \pm 1.3 \mathrm{~min}$ after this higher dose of flumazenil. Aqueous humour pressure returned to pre-flumazenil values at $2.3 \pm 1.5 \mathrm{~min}$. Peak aqueous humour pressure was not significantly different from pre-midazolam (baseline) aqueous humour pressure. The higher dose of flumazenil increased MAP by $13 \pm 9 \mathrm{mmHg}(P<0.05)$.

\section{Discussion}

One principal finding of this study was that flumazenil increased aqueous humour pressure in halothane-anaesthetized dogs receiving midazolam, but not in dogs not receiving midazolam. This was true both when aqueous humour pressure was normal and when aqueous pressure was elevated before administration of flumazenil. At both normal and elevated aqueous humour pressure the increase of aqueous humour pressure was to pre-midazolam values. These results indicate that flumazenil increased aqueous humour pressure due to reversal of benzodiazepine effect and not due to a direct agonist action of flumazenil. There are several possible mechanisms by which flumazenil-induced reversal of midazolam may increase aqueous humour pressure.

The most dramatic increases of IOP are produced by reduction of aqueous outflow ${ }^{6,15}$ One cause for reduced aqueous outflow is increased pressure in ophthalmic veins due to increased intrathoracic venous pressure. In the present study pancuronium was used to maintain muscle relaxation so it is unlikely that increase of aqueous humour pressure occurred in response to contraction of the thoracic muscles. Central venous pressure was not measured in the present study, but it was previously reported that central venous pressure did not change significantly when flumazenil was used to reverse benzodiazepine sedation in cardiac surgery patients. ${ }^{*} \mathrm{~A}$ second cause for reduced aqueous outflow is narrowing of the angle of the anterior chamber due to pupillary dilation. Anxiety responses (which may include pupillary dilation) previously were reported in some patients when flumazenil was given following benzodiazepine administration. $\dagger \ddagger$ Pupillary diameter was not measured in the

*Louis M, Forster A, Suter PM, Gemperle M. Clinical hemodynamic effects of a specific benzodiazepine antagonist (Ro 15-1788) after open heart surgery. Anesthesiology 1984; 61: A61.

†Louis $M$, Forster A, Suter PM, Gemperle $M$. Clinical hemodynamic effects of a specific benzodiazepine antagonist (Ro 15-1788) after open heart surgery. Anesthesiology 1984;61: A61.

‡Geller E, Niv D, Matzkin C, Silbiger A, Nero I, Cohen F, Braf $Z$. The antagonism of midazolam sedation by Ro 15-1788 in 50 postoperative patients. Anesthesiology 1985; 63: A369. present study, so the possibility that aqueous humour pressure increased secondary to pupillary dilation cannot be excluded.

Less dramatic increases of IOP are produced by increase of blood pressure, ${ }^{6}$ hypercapnia, ${ }^{16}$ contraction of extraocular muscles, ${ }^{6}$ activity of the diencephalon, ${ }^{6.17}$ catecholamines, ${ }^{18}$ and increase of ciliary blood flow. ${ }^{19}$ In the present study flumazenil $0.16 \mathrm{mg} \cdot \mathrm{kg}^{-1}$ increased aqueous humour pressure with (Group 4) or without (Group 3) an accompanying increase of MAP, expired $\mathrm{CO}_{2}$ was maintained at a constant value by servoregulation of ventilation, and pancuronium was used to maintain muscle relaxation. Thus, these are unlikely causes for the increases of aqueous humour pressure observed here. It is possible that aqueous humour pressure increased secondary to increased activity of the diencephalon. Flumazenil previously was reported to increase the activity of the electroencephalogram in dogs and patients given midazolam. ${ }^{12.20} \mathrm{It}$ is also possible that increase of aqueous humour pressure resulted from stimulation of the sympathetic nervous system and release of catecholamines. Topical application of dopamine was reported to produce a modest elevation of IOP within the first hour following installation. ${ }^{18} \mathrm{~A}$ third possibility is that flumazenil increased ciliary blood flow, resulting in increased aqueous humour pressure. The vascular responses of the ciliary processes are similar to that of the choroid plexus, ${ }^{19}$ and flumazenil previously was reported to increase cerebral blood flow (by $44-100 \%$ ) in dogs given midazolam. ${ }^{11,12}$

The second principal finding of this study was that even though aqueous humour pressure following flumazenil was statistically increased compared with that during infusion of midazolam, the increase of aqueous humour pressure that occurred under the conditions of this study is not likely to be clinically important. The magnitude of increase of aqueous humour pressure was within the range of normal variability of aqueous humour pressure for the dogs in this study. Additionally, aqueous humour pressure after administration of flumazenil was not different than aqueous humour pressure prior to administration of midazolam (baseline). Again, this was true both when aqueous humour pressure was normal and when aqueous humour pressure was elevated prior to administration of flumazenil.

The invasive technique for measurement of aqueous humour pressure used in this study was selected because it provides continuous information and is relatively free of operator error. Alternative methods for measuring aqueous humour pressure include applanation tonometry ${ }^{21}$ and the Schoitz indentation method. ${ }^{22}$ Certain findings from this and previous studies support the validity of the present technique relative to the alternative methods for 
detection of increases of aqueous humour pressure over a time period of $135 \mathrm{~min}$ in anesthetized animals. Both this technique ${ }^{13}$ and the noninvasive ones ${ }^{6}$ detect increases of IOP in response to increases of blood pressure or central venous pressure. Baseline aqueous humour pressure and the variability of aqueous humour pressure as determined with this technique were similar to values previously reported using the noninvasive techniques. ${ }^{6.19}$ Stability of aqueous humour pressure and pressure variability for 135 $\min$ in Groups 1 and 2 indicates no decrement in the accuracy or reliability of this technique over the period of the study. Restoration of aqueous humour pressure to pre-flumazenil values within $12 \mathrm{~min}$ of administration of flumazenil in Groups 3 and 4 indicates that this technique did not eliminate the mechanisms that usually operate to maintain intraocular pressure at "normal" levels.

The findings of the present study suggest that clinically important increases of IOP may not occur when flumazenil is used to reverse benzodiazepine effects in patients with or without pre-existing elevation of IOP or decrease of intraocular compliance. Moreover, using a greater-thaneffective dose of flumazenil should not increase the risk of clinically important increase of IOP. The same may be true when flumazenil is used to reverse the central effects of nonbenzodiazepines that interact with benzodiazepine receptors, such as cyclopyrrolones, beta-carbolines, triazolopyridazines and phenylquinolines. ${ }^{23-25 *}$ The findings further suggest that no increases of IOP may occur when flumazenil is given to patients who have not received medications that interact with benzodiazepine receptors.

It should be noted that the data from the present canine studies cannot be applied to clinical practice until they are confirmed in studies with human patients or volunteers. Certain differences do exist between canine and human eyes. The eye of the dog is less compliant and the ciliary angle is supplied with a rich venous plexus that plays a major role in the reabsorption of aqueous humour. In man the ciliary angle is largely obliterated and a specialized structure, the Canal of Schlemm, plays a major role in the reabsorption of aqueous humour.

\section{References}

1 Fragen RJ, Hauch $T$. The effect of midazolam maleate and diazepam on intraocular pressure in adults. Arzncimittelforschung 1981; 31: 2273-5.

2 Pinto G, Silvi MB, Basili P, Gasparetto A. Midazolam as an induction agent for surgery of the anterior segment of the cye. Ann Fr Anesth Reanim 1984; 3: 339-41.

*Frost JJ, Dannals RF, Ravert HT et al. Imaging benzodiaze pine receptors in man with $\mathrm{C}$ - 11 -suriclone and positron emission tomography. J Nucl Med 1985; 26: 52.
3 Hirlinger WK, Wick C, Stodtmeister R. Comparative study of the behavior of intraocular pressure in anesthesia induction by diazepam and midazolam. Anasthesie Intensivtherapie Notfallmedizin 1986; 21 : 324-6.

4 Duncalf $D$, Foldes FF. Effect of anesthetic drugs and muscle relaxants on intraocular pressure. Int Ophthalmol Clin 1973; 13: 21-33.

5 Maillet J. Perier JF, Girard P, Maillet A, Forest A, Delingue $P$. Effects of flunitrazepam on intraocular pressure. J Fr Ophtalmol 1982; 5: 335-8.

6 Donlon JV Jr. Anesthesia for eye, ear, nose, and throat. In: Miller RD (Ed.). Anesthesia, New York: Churchill Livingstone, 1986; 1837-94.

7 Schottenstein EM. Intraocular pressure. In: Ritch $\mathbf{R}$, Shields MB, Krupin T (Eds.). The Glaucomas, St. Louis: The C.V. Mosby Company, 1989: 301-17.

8 Adams $A K$, Jones $R M$. Anaesthesia for eye surgery: gencral considerations. Br J Anaesth 1980; 52: 663-9.

9 Gobeaux D. Sardnal F. Midazolam and flumazenil in ophthalmology. Acta Anaesthesiol Scand Suppl 1990; 92: 35-8.

10 Chiolero $R$, Ravussin $P$, Chassot $P$ - $G$, Neff $R$, Freeman $J$. RO 15- 1788 for rapid recovery after craniotomy. Anesthesiology 1986; 65: A466.

11 Fleischer JE, Mi Ide JH, Moyer TP, Michenfelder $J D$. Cerebral effects of high dose midazolam and subsequent reversal with Ro 15-1788 in dogs. Anesthesiology 1988; 68: 234-42.

12 Artru AA. Flumazenil reversal of midazolam in dogs: dose-related changes in cerebral blood flow, metabolism EEG, and CSF pressure. J Neurosurgical Anesthesiology 1989; 1: 46-55.

13 Schreuder $M$, Linssen $G H$. Intra-ocular pressure and anaesthesia. Anaesthesia 1972; 27: 165-70.

14 Jay JL. Functional organization of the human eye. $\mathrm{Br} \mathrm{J}$ Anacsth 1980; 52: 649-54.

15 Holloway KB. Control of the eye during general anacsthesia for intraocular surgery. Br J Anacsth 1980; 52: 671-9.

16 Samuel JR, Beaugie A. Effect of carbon dioxide on the intraocular pressure in man during general anacsthesia. Br J Ophthalmol 1974; 58: 62-7.

17 Scars $M$, Caprioli J, Kazuyoshi K, Bausher L. A mechanism for the control of aqueous humour formation. $I n$ : Drance SM, Neufeld AH (Eds.). Glaucoma: Applied Pharmacology in Medical Treatment, Orlando: Grune \& Stratton, Inc., 1984; 303-24.

18 Leopold IH, Potter DE, Duzman E, Novack GD. Pharmacology of ocular catecholamines. In: Tasman W, Jacger EA (Eds.). Duane's Biomedical Foundations of Ophthalmology, Philadelphia: J.B. Lippincott Company, 1989; 34.1-34.34. 
19 Brubaker RF. The physiology of aqueous humor formation. In: Drance SM, Neufeld AH (Eds.). Glaucoma: Applied Pharmacology in Medical Treatment, Orlando: Grunc \& Stratton, Inc., 1984; 35-70.

20 Klotz U. Ziegler G, Ludwig L, Reinmann IW. Pharmacodynamic interaction between midazolam and a specific benzodiazcpine antagonist in humans. J Clin Pharmacol 1985; 25: 400-6.

21 LeMay $M$. Aspects of measurement in ophthalmology. $\mathrm{Br}$ J Anaesth 1980; 52: 655-62.

22 Duke-Elder S, Smith RJH. The examination of the eye. In: Duke-Elder S (Ed.). A System of Ophthalmology: The Foundations of Ophthalmology: Heredity, Pathology, Diagnosis and Therapeutics, St. Louis: C.V. Mosby Company, 1962; 233-365.

23 Burkard WP, Bonetti EP. Haefely $W$. The benzodiazepine antagonist Ro 15-1788 reverses the effects of methylbeta-carboline-3-carboxylate but not of harmaline on cercbellar cGMP and motor performance in mice. Eur $\mathrm{J}$ Pharmacol 1985; 109: 24I-7.

24 Patel JB, Martin C, Malick JB. Differential antagonism of the anticonflict effects of typical and atypical anxiolytics. Eur J Pharmacol 1983; 86: 295-8.

25 Trifiletti RR, Snyder $S H$. Anxiolytic cyclopyrolones zopiclone and suriclone bind to a novel site linked allosterically to benzodiazepine receptors. Mol Pharmacol 1984; 26: 458-69. 